\title{
O006. Efficacy of prophylactic therapy in chronic primary headache with use of biofeedback
}

\author{
Biagio Ciccone ${ }^{1 *}$, Luigi Balzano², Giacinta D'Otolo ${ }^{3}$ \\ From Abstracts from the 1st Joint ANIRCEF-SISC Congress \\ Rome, Italy. 29-31 October 2015
}

\section{Introduction}

Retrospective study of patients with chronic tension headache $(\mathrm{CTH})$ and chronic migraine $(\mathrm{CM})$.

\section{Objective}

To compare the efficacy of biofeedback (BFB) compared to only prophylactic therapy in these primary headaches [1-4].

\section{Materials and methods}

We evaluated a total of 8 patients with $\mathrm{CTH}$ and 8 patients with CM. All patients had a history of primary headache and had never undergone prophylactic therapy. The observation period lasted 90 days. Four CTH patients and $4 \mathrm{CM}$ patients underwent only prophylactic therapy (amitriptyline $20 \mathrm{mg}$ daily), the remaining 4 $\mathrm{CTH}$ and $4 \mathrm{CM}$ prophylactic therapy and BFB training sessions. Assessment tools outcome measures were:

- Headache diary to assess days per month with headache;

- Analgesic consumption and/or triptans;

- Score of the visual analogue pain scale (VAS);

- SEMG parameter for patients who carried out BFB training.

\section{Results}

At the end of the 90 day observational period there was a significant improvement (reduction in headache days per month, in VAS score, in analgesic consumption and in SEMG parameter) in CTH and CM patients that had undergone both BFB training and prophylactic therapy when compared to the group of patients treated only with prophylactic therapy drug.

* Correspondence: ambulatorio@biagiociccone.it

${ }^{1}$ Ambulatorio ATHENA, Saviano (NA), Italy

Full list of author information is available at the end of the article

\section{Discussion and conclusions}

The overall data confirmed the efficacy of the BFB training in the prophylaxis of primary headaches, further supporting the benefits already possible with the therapy of only pharmacological prophylaxis (Table 1). The data also showed a clear dominance of efficacy, especially in the forms of chronic tension headache (Table 2).

Written informed consent to publication was obtained from the patient(s).

\section{Authors' details}

${ }^{1}$ Ambulatorio ATHENA, Saviano (NA), Italy. ${ }^{2}$ ASL NA3 SUD, Naples, Italy.

${ }^{3}$ Ambulatorio Athena, Saviano (NA), Italy.

Published: 28 September 2015

Table 1. Overall differences between the two groups after 90 days of therapy

\begin{tabular}{llllll}
\hline & Frequency & VAS & $\begin{array}{l}\text { Analgesic } \\
\text { consumption }\end{array}$ & $\begin{array}{l}\text { Triptan } \\
\text { consumption }\end{array}$ & SEMG \\
\hline CTH & $-58 \%$ & $-37 \%$ & $-62 \%$ & & \\
\hline CTH BFB & $-75 \%$ & $-67 \%$ & $-86 \%$ & $-54 \%$ \\
\hline CM & $-53 \%$ & $-34 \%$ & $-60 \%$ & $-50 \%$ & \\
\hline CM BFB & $-61 \%$ & $-43 \%$ & $-75 \%$ & $-63 \%$ & $-54 \%$ \\
\hline
\end{tabular}

Table 2. Differences between CTH and $\mathrm{CM}$ in treatment with BFB after 90 days of therapy

\begin{tabular}{lllll}
\hline & Frequency & VAS & $\begin{array}{l}\text { Analgesic } \\
\text { consumption }\end{array}$ & SEMG \\
\hline CTH BFB & $-75 \%$ & $-67 \%$ & $-86 \%$ & $-54 \%$ \\
\hline CM BFB & $-61 \%$ & $-43 \%$ & $-75 \%$ & $-54 \%$ \\
\hline $\begin{array}{l}\text { Difference CTH BFB } \\
\text { and CM BFB }\end{array}$ & $-14 \%$ & $-24 \%$ & $-11 \%$ & $-50 \%$ \\
\hline
\end{tabular}




\section{References}

1. Nestoriuc $Y$, Martin A, Rief W, Andrasik F: Biofeedback treatment for headache: a comprehensive efficacy review. Appl Psychophysiol Biofeedback 2008, 33(3):125-140.

2. Holroyd KA, Penzien DB: Pharmacological versus non-pharmacological prophylaxis of recurrent migraine headache: a meta-analytic review of clinical trials. Pain 1990, 42(1):1-13.

3. Andrasik F: Biofeedback in headache: an overview of approaches and evidence. Cleve Clin J Med 2010, 77(Suppl 3):S72-S76.

4. Nestoriuc Y, Rief W, Martin A: Meta-analysis of biofeedback for tensiontype headache: efficacy, specificity, and treatment moderators. J Consult Clin Psychol 2008, 76(3):379-396.

doi:10.1186/1129-2377-16-S1-A134

Cite this article as: Ciccone et al:: O006. Efficacy of prophylactic therapy in chronic primary headache with use of biofeedback. The Journal of Headache and Pain 2015 16(Suppl 1):A134

\section{Submit your manuscript to a SpringerOpen ${ }^{\odot}$ journal and benefit from:}

- Convenient online submission

- Rigorous peer review

- Immediate publication on acceptance

- Open access: articles freely available online

- High visibility within the field

- Retaining the copyright to your article

Submit your next manuscript at $>$ springeropen.com 